\title{
OS MOVEMENTOS SOCIAIS E A SOCIEDADE CIVIL: \\ DE COMO OS EMERXENTES CONFLITOS SOCIAIS CUESTIONAN AS PERSPECTIVAS ADOPTADAS POLAS CIENCIAS SOCIAIS
}

\section{Donatella della Porta}

European University Institute (Florencia) 



\section{INTRODUCIÓN AO CONFLITO, A CIDADANÍA, OS MOVEMENTOS SOCIAIS E A SOCIEDADE CIVIL}

O 2 de xullo de 2005 máis de 200000 persoas marcharon sobre Edimburgo, uns poucos días antes do cumio do G-8 realizado no veciño Gleneagles, no que se chamou con satisfacción a maior manifestación que tivera lugar na capital escocesa. A marcha formaba parte da campaña Make Poverty History («Fai que a pobreza pase á historia»), definida polo arcebispo O'Connor como «o maior movemento de axitación visto desde a campaña en contra do tráfico de escravos». Ao longo da semana seguinte, mentres os líderes do G-8 mantiñan as súas xuntanzas, tiveron lugar moitas máis protestas, de diversa índole, en diferentes puntos do sur de Escocia, organizadas principalmente por activistas afiliados á rede Dissent! («Discrepa!»), a cal se formara había pouco. As forzas policiais de diversos corpos británicos, a miúdo completamente enfundadas no seu equipamento antidisturbios, enfrontáronse aos manifestantes no que se definiu como a maior operación policial da historia escocesa.

Make Poverty History e outras protestas similares considéranse parte dun movemento de reivindicación da xustiza global que adquiriu visibilidade mundial en Seattle en novembro de 1999, no transcurso da campaña contra o cumio da Organización Mundial de Comercio (OMC). En anos posteriores, centos de milleiros de persoas manifestáronse contra as reunións do Fondo Monetario Internacional (FMI) e do Banco Mundial (BM) realizadas en Washington e en Praga no ano 2000, contra o G-8 en Xénova en 2001, contra os cumios da Unión Europea (EU) de Ámsterdam en 1997, de Niza en 2000, de Goteburgo en 2001, e de Barcelona, Sevilla e Copenhague en 2002. A xente protestou contra o Foro Económico Mundial en manifestacións anuais organizadas en Davos, e contra a guerra de Iraq, en centos de cidades, durante o Día de Acción Mundial 
(15 de febreiro de 2003). En relación con esta vaga de protestas, milleiros de asociacións de diverso tipo e decenas de miles de activistas reuníronse en foros sociais transnacionais; abonda con lembrar que ao primeiro Foro Social Mundial (FSM), celebrado en Porto Alegre en xaneiro de 2001, asistiron arredor de 20000 de máis de cen países, entre os cales se contaban delegados de 4700 ONG e organizacións defensoras dos movementos sociais, cifras que ascenderon a 155000 participantes individuais e 6588 organizacións na súa quinta edición, en 2005 (Rucht 2005). O primeiro Foro Social Europeo (FSE), que tivo lugar en Florencia entre o 6 e o 9 de novembro de 2002, acolleu 60000 participantes -máis do triplo do que se esperaba-, que asistiron ás 30 conferencias plenarias, aos 160 seminarios e aos 180 obradoiros, e arredor dun millón de persoas tomaron parte na marcha que clausurou o foro.

Cando esta vaga de protestas se fixo visible, no cambio de milenio, os expertos en ciencias sociais seguían dedicándose a explicar a «oeneguización»dos movementos sociais, a domesticación da sociedade civil e a morte dos sindicatos e da política de esquerdas en xeral. Só de xeito gradual a intensa mobilización transnacional organizada en cumios alternativos, en Días de Acción Mundial e en Foros Sociais transnacionais comezou a crear conciencia do xurdimento dun novo ciclo de protestas e a atraer o interese da poboación por tal feito.

Abofé que non é unha novidade que se dean inesperadamente ciclos de protestas. Así, en vésperas de 1968, tanto os expertos en ciencias sociais como os políticos lamentaban (ou loaban) a «fin das ideoloxías», a institucionalización do movemento obreiro, a sociedade de consumo e, sobre todo, o declive do interese pola política.

A impresión que causan estas mudanzas inesperadas podería deberse a diferentes motivos. Sen dúbida, o comezo dun novo ciclo de protestas dá fe, xaora, dun rachar coas formas preponderantes de acción colectiva e de estratexia organizativa, así como coas das identidades colectivas. Neste sentido, a percepción de que se produciu unha ruptura repentina reflicte como os ciclos de protestas cuestionan os modos en que nese momento se aborda a acción colectiva. As transformacións sociais e políticas que tiveron lugar durante a que foi, en palabras dun activista, «a terrible década de 1990» levaron, de feito, a mudanzas significativas (aínda que de escasa repercusión) nos actores que se definen, de modo diverso, como movementos sociais, ONG ou sociedade civil. 
Malia producirse a miúdo de xeito inesperado, un ciclo de protestas non comeza tan de socato como podería parecer. A protesta require da existencia dunhas estruturas organizativas capaces de mobilizaren recursos, xunto cuns procesos, menos visibles, de interconexión e de preparación de xustificacións da acción colectiva. Os movementos sociais emerxentes están moi influídos polas características das organizacións que os «acubillan» durante a súa infancia, e a súa evolución é o produto dunha mestura de tradicións e de contradición desas mesmas tradicións. As protestas que acabo de mencionar deriváronse de diversas campañas que reuniron a organizacións xa existentes nun movemento contrario ao Tratado de Libre Comercio de América do Norte (NAFTA) e ao Acordo Multilateral sobre Investimentos, ademais da campaña Xubileu 2000, que pedía a cancelación da débeda externa dos países pobres. No marco dunha estratexia emprendida a varios niveis, as Marchas Europeas contra o Paro e a Exclusión, definidas como un primeirísimo exemplo da formación dunha rede flexible destinada a abordar os problemas sociais a escala europea (Mathers 2007: 51), tornáronse en visibles o 16 e o 17 de xuño de 1997, cando 5000 persoas de toda Europa chegaron a Ámsterdam co cumio da UE en mente. Estes cumios alternativos aos da UE, que nun principio foran artellados por organizacións de parados e de sindicatos críticos, foron dando en tratar un abano cada vez maior de problemas e tamén conseguiron sensibilizar, entre outros, as confederacións sindicais institucionalizadas, así como diversas comunidades relixiosas, ONG transnacionais e locais, ecoloxistas, feministas e pacifistas. No entanto, dado que estas campañas non respondían á imaxe xeneralizada de actores sociais cada vez máis "civilizados», acabaron por ser pouco estudadas.

A percepción dunha brusca ruptura na acción colectiva tamén constitúe, polo menos en parte, o resultado do natural conformismo das ciencias sociais, nas cales as tendencias xerais (como a burocratización dos sindicatos, a domesticación da sociedade civil ou a institucionalización das organizacións en prol dos movementos sociais) adoitan confirmarse grazas á escolla de determinadas materias de estudo (por exemplo, o liderado sindical ou unhas ONG máis visibles e mellor estruturadas) e a exclusión doutras. Á inversa, semella que non se fomenta a identificación de tendencias opostas ás que se acaban de citar; antes ao contrario, debido á súa falta de visibilidade ou relevancia no marco do paradigma ou paradigmas dominantes. Ao mesmo tempo, nunha especie de profecía 
que se cumpre a si mesma, as escollas metodolóxicas tenden a adecuarse ás imaxes xeneralizadas: por exemplo, dando por suposta a importancia dos recursos empresariais, as análises das organizacións revelan unha inclinación cara a grupos mellor estruturados; e, fronte á «normalización» das protestas, ante a baixada na atención que lles prestan os medios de comunicación ás formas non convencionais de participación política, as análises dos actos de protesta confirman o declive da política nas rúas.

Non obstante, non pretendo insinuar que as ciencias sociais carezan de conceptos e coñecementos que contribúan a abordar, enmarcar e entender estes conflitos; ao revés, existen diversas correntes de estudos que contan cun gran potencial para axudaren a interpretar os actores que se mobilizaron desde Seattle ata Edimburgo. Por exemplo, a campaña Make Poverty History reuniu centos de entidades benéficas, sindicatos, credos, sindicatos de estudantes, grupos de base..., é dicir, organizacións que, na socioloxía política, se tratan dentro do vasto eido dos estudos dos movementos sociais (definidos por oposición aos grupos de partidos políticos e de intereses); nas relacións internacionais, no marco dun interese cada vez maior polas ONG (e non polos Estados-nación); na teoría social, como parte do «renacer» da sociedade civil (en contraposición ao Estado e ao mercado). $\mathrm{O}$ mesmo se pode dicir dos demais cumios alternativos, días de acción global e foros sociais transnacionais, aos cales asisten representantes de milleiros de asociacións e decenas de miles de activistas. Os estudosos das organizacións dos movementos sociais, das ONG e da sociedade civil tamén se apresuraron a estender o seu ámbito de interese á nova dimensión supranacional destas mobilizacións, mediante conceptos como "organizacións transnacionais», «ONG internacionais» e "sociedade civil mundial». Malia que, con frecuencia, non manteñen comunicación entre eles, estes campos de estudo teñen moito que ofrecernos á hora de entendermos estes conflitos que van xurdindo na nosa sociedade.

As análises dos movementos sociais levan moito tempo a subliñar que o conflito é o elemento en que se basea a dinámica das sociedades. Nestas análises, a «tradición europea» considera os novos movementos sociais como potenciais portadores dun outro conflito de importancia fundamental nas nosas sociedades postindustriais ou, polo menos, dun abano de conflitos emerxentes. $\mathrm{Na}$ «tradición norteamericana», o enfoque referido á mobilización de recursos reaccionou 
ante unha concepción, daquela dominante, dos conflitos como patoloxías. $\mathrm{Na}$ súa influente obra Social Conflicts and Social Movements, Anthony Oberschall (1973) definiu os movementos sociais como os principais portadores de conflitos sociais. En Democracy and Disorder, Sidney Tarrow sinalou enerxicamente o papel, importante e positivo, que desempeñan as formas non convencionais de participación política nos procesos democráticos. Desde Michael Lipsky (1965) ata Charles Tilly (1978), as primeiras obras que abordaron sistematicamente o tema dos movementos sociais xurdiron de tradicións investigadoras que facían fincapé nos conflitos de poder, tanto na sociedade como na política; de feito, existe unha definición dos movementos sociais que goza de ampla aceptación e que presenta os conflitos como un elemento vital da conceptualización deses movementos:

Os actores implicados nos movementos sociais toman parte en conflitos políticos, culturais ou de ambos os tipos, os cales teñen como fin promover o cambio social ou oporse a el. Co termo "conflito» referímonos a unha relación de oposición entre actores que pretenden controlar os mesmos intereses - xa sexa o poder político, o económico ou o cultural- e, ao así actuaren, realizan declaracións negativas os uns en contra dos outros; é dicir, demandas que, de se cumpriren, afectarían aos intereses dos demais actores (Della Porta e Diani 2006: 21).

Xa que logo, as análises dos movementos sociais poden contribuír a contrarrestar a actual tendencia a percibir os conflitos como patoloxía.

Aínda que non se nega, xaora, a existencia de conflitos, especialmente desde a década de 1990 a concepción da política en canto campo de expresión de conflitos foi posta en dúbida (ou, polo menos, compensada) pola atención que comezou a prestárselle ao desenvolvemento de eidos comunicativos que puidesen funcionar como espazos onde construír un consenso. Na teoría normativa, mais tamén na investigación empírica, o interese polos espazos de comunicación autónomos foi crecendo particularmente no marco da análise da sociedade civil; así, definido como "o elemento favorito que se pode exportar desde a teoría sociolóxica á política» (Mitzal 2001), mais tamén como "plano e carente de contido» (Chandoke 2003), o concepto de «sociedade civil» tense empregado como sinónimo de vida asociativa e de emancipación do poder 
estatal. Inspirada, en especial, nos novos movementos sociais e no movemento pola democracia en Europa oriental (Mitzal 2001), na teoría social a "renacenza» da sociedade civil viviuse sobre todo na década de 1990, coa procura dun espazo que fose independente tanto do Estado como do mercado. De feito, «tras a revolución de 1989, o termo "sociedade civil" adoptouse en círculos e circunstancias sumamente diferentes», o cal expresaba que "era salientable xa a preocupación pola autonomía persoal, a autoorganización, o espazo privado, e non só en Europa occidental» (Kaldor 2003: 2-4). A sociedade civil constitúe «unha esfera de solidariedade onde se vai definindo e, en certa medida, levando á práctica un determinado tipo de comunidade universalizadora» (Alexander 1998: 7). Desde esta perspectiva, a urbanidade implica respecto polos demais, cortesía e aceptación dos descoñecidos (Keane 2003). En moitas das reflexións sobre as sociedades contemporáneas, unha sociedade civil autónoma enténdese como un ente capaz de abordar as tensións existentes entre particularismo e universalismo, pluralidade e conexión, diversidade e solidariedade; e, neste sentido, afírmase que representa esa esfera de solidariedade da que acabamos de falar (Alexander 1998: 7). Así mesmo, algúns defensores da visión deliberativa e normativa da democracia consideran os movementos sociais e outros modos de asociación similares uns ámbitos fundamentais para o desenvolvemento desas esferas públicas autónomas (Mansbridge 1996; Cohen 1989; Dryzek 2000; Offe 1997). $\mathrm{Na}$ análise dos conflitos contemporáneos tamén resulta crucial ese facer fincapé, en termos normativos, nos efectos positivos dos espazos independentes do Estado e do mercado.

Ambos os dous elementos - conflito e autonomía- son pertinentes á hora de entender as características das mobilizacións que mencionei. A pesar disto, algúns trazos dos novos conflitos emerxentes comportan certa dúbida dos enfoques teóricos arriba indicados, ao tempo que estimulan unha maior fecundación recíproca entre estas diversas correntes que se dan nas obras dedicadas ás ciencias sociais. Unha visión máis minuciosa e aberta dos conflitos emerxentes podería contribuír a superar o risco de incorrer en autorreferencias e en estreitezas de miras que puidese derivarse do propio éxito desas correntes (ante o crecente número de revistas, cátedras, etc., referidos a eses conceptos básicos), mais tamén da consolidación de fendas internas entre os enfoques disciplinarios, metodolóxicos e nacionais. 
Nas seccións que van a seguir, baseándome en resultados extraídos dos estudos empíricos que realicei sobre a clase de conflitos mencionados ${ }^{1}$, pretendo destacar como a súa propia natureza fixo que cambaleasen algunhas das imaxes dominantes e a interpretación preponderante dos movementos, das ONG e dos actores da sociedade civil. Querería, en concreto, chamar a atención sobre a centralidade que adquiriron os problemas sociais, malia que tendendo unha ponte entre este e outro dos temas principais (parte 2), e sobre unha redefinición da política e os seus límites (parte 3), no marco dunha avaliación do papel que desempeñan os conflitos na creación de cidadanías (parte 4).

\section{CONFLITOS E FENDAS SOCIAIS: POLÍTICA DE CLASE OU SUBXECTIVIDADES CÍVICAS?}

Como se mencionou, un elemento máis positivo achegado polos estudos dos movementos sociais é a reinstauración da función que desempeñan os conflitos na evolución dunha sociedade. Os conflitos sociais e políticos téñense vinculado coas condicións socioestruturais (desde as estruturas de produción marxistas ata a produción da historicité de Touraine) ou coa apertura de canles de acceso á adopción pública de decisións, ou con ambas. Nos dous casos, o Estado-nación tomouse como o principal nivel de análise dunha investigación que destaca e aborda o vello conflito laboral ou os novos.

Cando os estudos dos movementos sociais tomaron corpo como importante eido sociolóxico, no transcurso do ciclo de protestas presenciadas a finais da

\footnotetext{
${ }^{1}$ Entre outras cuestións, voume referir a algúns resultados que se publicaron nos Paquetes de Traballo 3 e 4 do proxecto DEMOS (Democracia en Europa e Mobilización Social, http://demos.iue.it); véxase Della Porta e Mosca (2006). Este proxecto está financiado pola COMisión EUropeA, PRIORIDAde 7 do SeXTo Programa MARCO: «Os cidadáns e o goberno dunha sociedade do coñecemento», e (para o caso suízo) polo Departamento Federal de Educación e Ciencia (Suíza). O proxecto está coordinado por Donatella della Porta (European University Institute); están asociados a University of Kent (Canterbury, Reino Unido), con Christopher C. Rootes; o Wissenschaftszentrum Berlin für Sozialforschung, (Alemaña), con Dieter Rucht; a Università di Urbino (Italia), con Mario Pianta; o Centre de Recherches Politiques de la Sorbonne (CRPS), da Universitè Panthéon-Sorbonne (Francia), con Isabelle Sommier; o Instituto de Estudios Sociales de Andalucía, do Centro Superior de Investigaciones Científicas (IESA-CSIC) (España), con Manuel Jiménez; e o Laboratoire de Recherches Sociales et Politiques Appliquées (RESOP), da Université de Genève (Suíza), con Marco Giugni. Colaboraron na investigación Massimiliano Andretta, Ángel Calle, Hélène Combes, Nina Eggert, Raffaele Marchetti, Lorenzo Mosca, Herbert Reiter, Clare Saunders, Simon Teune, Mundo Yang e Duccio Zola.
} 
década de 1960 e principios da de 1970, os intelectuais europeos centráronse sobre todo nos novos movementos sociais, desenvolvendo a crenza pola que se postulaba a institucionalización da clase traballadora e a aparición de máis conflitos postindustriais (véxase, por exemplo, Touraine 1977). Especialmente na década de 1970, os movementos ambientais, feministas e mesmo pacifistas e etnorrexionalistas foron considerados as "parteiras» dun novo tipo de sociedade que sucedía á industrial, materialista, fordista ou moderna, ou a todas elas. A liberdade individual como valor fundamental, xunto coa xustiza (e, por veces, anteposta a ela), recibiu tamén moita atención por parte dalgúns teóricos da sociedade civil.

A unha escala máis modesta, a partir da década de 1980 eses movementos pasaron a ser vistos progresivamente como actores institucionalizados, ricos en recursos materiais e en canles de acceso aos gobernantes, e cada vez máis centrados en problemas illados. En efecto, esta atención a un único problema chegou a considerarse un trazo característico dos movementos sociais que os distingue dos partidos e dos sindicatos (Kitschelt 2004), e, paralelamente, as obras dedicadas ás ONG fan fincapé en como estes actores se especializan nun tema concreto, que se aborda no marco duns réximes internacionais dados. A sociedade civil mundial tense definido como un ente formado por organizacións profesionalizadas, institucionalizadas e centradas nunhas causas concretas (Kaldor 2003).

No entanto, esta imaxe que as presentaba como actores posmaterialistas e dedicados a unha única cuestión viuse sacudida na década de 1990 e derrubouse despois do ano 2000. Efectivamente, desde o pasado decenio, as reaccións suscitadas polo que os activistas denominan «neoliberalismo hexemónico» trouxeron consigo un rexurdimento dos problemas sociais, aínda que en conxunción coas cuestións derivadas dos «novos movementos sociais». É máis, os actos de protesta transnacionais multiplicáronse nas dúas últimas décadas, o que indica un «cambio de escala» que apunta á adopción dunha perspectiva máis transversal. A combinación de varios temas de interese e a importancia de abordar a cuestión da xustiza social son, ambas as dúas, consecuencias senlleiras dunha análise de documentos fundamentais referidos a 244 organizacións de movementos sociais que participaron nos procedementos do Foro Social en seis países europeos (Italia, Francia, Alemaña, Gran Bretaña, España e Suíza) e a escala 
transnacional ${ }^{2}$. Os datos (véxase a táboa 1) referentes aos temas e aos valores básicos mencionados nos documentos organizativos confirman que a miúdo se fai referencia a cuestións que noutros tempos constituíron o principal foco de atención de varios movementos sociais. Neste sentido, os valores ecolóxicos resultan ser un tanto importantes (arredor da metade dos grupos citan a ecoloxía e a mesma porcentaxe menciona a sustentabilidade). $\mathrm{O}$ sur do planeta figura nos documentos básicos de aproximadamente a metade dos grupos que demandan solidariedade cos países do Terceiro Mundo; a mesma porcentaxe defende os dereitos humanos; e un terzo refírese ao comercio xusto. Tamén se inclúen mencións aos dereitos das mulleres e á paz (máis unha vez, na metade dos grupos da mostra), ao igual que aos dereitos dos inmigrantes. Porén, estes marcos temáticos cítanse no seo dun discurso transversal. Por outra banda, aínda que son moito menos xerais as referencias ás tradicionais ideoloxías de esquerdas (desde o socialismo e o comunismo ata o anarquismo), desempeñan unha función de «enlace» marcos como «xustiza social» (case dous terzos dos nosos grupos a mencionan), "xustiza mundial», "globalización alternativa» e "democracia alternativa» (citadas por preto da metade dos grupos).

Dentro do mesmo proxecto de investigación, as entrevistas mantidas con representantes das organizacións dedicadas aos movementos sociais confirman que se pasou da adopción de compromisos sobre un tema concreto a outros «transtemáticos», sen que iso supoña, con todo, unha volta a ideoloxías máis amplas. As respostas ofrecidas á pregunta aberta de «en que consiste a organización» indican, primeiramente, a difusión dunha linguaxe dos dereitos, empregada por case todos os grupos; de feito, con maior ou menor insistencia, os sindicatos reclaman "dereitos colectivos», e as organizacións próximas ao Novo Movemento Social, «dereitos civís», mentres que as implicadas en campañas a prol do sur do mundo espallan unha linguaxe referida aos «dereitos humanos», que no movemento pola xustiza mundial logo se tornan en

\footnotetext{
${ }^{2}$ A análise centrouse nos seguintes documentos organizativos: a) a constitución da organización; b) un documento que contivese os seus valores fundamentais ou o propósito da organización, ou ambos; c) un programa aprobado de maneira oficial; d) a «declaración da misión» da organización; e) a sección «Sobre nós» do sitio web; f) a sección «Preguntas máis frecuentes» do sitio web; e g) materiais equivalentes ou similares, contidos no sitio web, que expresen a postura "oficial» da organización no seu conxunto (por exemplo, documentación interna á que se refiran os documentos a)-f), como informes anuais, formularios de adhesión de novos membros, etc.). Pódese obter máis información sobre a metodoloxía en Della Porta e Reiter (2006).
} 
TÁbOA 1. ValoRes básicos E temática (EN PORCENTAXE DE RESPOSTAS AFIRMATIVAS; NÚMERO DE ORGANIZACIÓNS: 244)

Marcos xeneralizados Temática de menor difusión

\begin{tabular}{llll}
\hline Xustiza social & $69 \%$ & Socialismo & $8 \%$ \\
\hline Outra democracia & $52 \%$ & Comunismo & $3 \%$ \\
\hline Outra globalización & $50 \%$ & Anarquismo & $4 \%$ \\
\hline Paz & $50 \%$ & Principios relixiosos & $7 \%$ \\
\hline Ecoloxía & $47 \%$ & & \\
\hline Dereitos humanos & $47 \%$ & & \\
\hline Xustiza mundial & $45 \%$ & & \\
\hline Dereitos dos emigrantes & $46 \%$ & & \\
\hline Solidariedade co sur & $46 \%$ & & \\
\hline Dereitos das mulleres & $43 \%$ & &
\end{tabular}

Fonte: Della Porta e Reiter (2006)

«dereitos mundiais». A base de referencia do movemento rara vez queda circunscrita a grupos de poboación concretos; a cidadanía esténdese a todos os residentes e alén deles e, así, o «movemento dos cidadáns do mundo» define a estes como a Humanidade, reclamando «respecto dos dereitos humanos para todos».

Así mesmo, os problemas sociais menciónanos, dun xeito ou doutro, a meirande parte dos enquisados. Destas cuestións, a xustiza social é o obxectivo que máis se cita; en palabras do representante da organización italiana para o desenvolvemento Emergency, o movemento a prol da xustiza mundial pretende «afirmar a igualdade entre os seres humanos, facendo fincapé nos dereitos humanos e na redución das diferenzas, propósitos que poden resumirse no termo "xustiza social"». Esta xustiza enténdese en termos distintos en función das diversas tradicións; así, os problemas sociais poden abordarse no sentido de «expoñer o escándalo da pobreza» -na linguaxe das ONG ou da relixión- ou no sentido de explotación e de «reasignación da riqueza de arriba abaixo» -na xerga tradicional de esquerdas. No entanto, na maioría dos grupos a xustiza social percíbese como o "marco intermediario" que conecta todos os demais; deste xeito, segundo afirma o representante de Espacio Alternativo: «existe unha gran diversidade, mais tamén unha tendencia a unificalos no seo dunha idea xeral e pluridimensional da xustiza social: social, ecolóxica, entre sexos, entre pobos e culturas, democrático-participativa e pola defensa do ben común». 
Significa isto un claro retorno a unha «visión clasista» da sociedade, esa visión sobre a que se desenvolveu a socioloxía no pasado e cuxa recente perda de apoios se considera a base do declive da disciplina (Savage 2001)? Pois ben, estas circunstancias indican, abofé, os límites das interpretacións polas que se lle dá relevancia á chamada «institucionalización da fenda entre clases», ou que opuñan os valores posmaterialistas aos materialistas. Máis en xeral, constitúen unha advertencia contra o que, de xeito demasiado simplista, se considera unha tendencia e que, en troques, podería formar parte dunha dinámica cíclica.

Con todo, isto non se pode entender como unha volta á antiga política de clases de sempre, debido a polo menos dúas razóns fundamentais. En primeiro lugar, como se mencionou, as preocupacións sociais están ligadas con outros problemas; ademais, ese movemento emerxente presenta tamén unha clara referencia á defensa da autonomía da sociedade civil, a cal resulta difícil de inserir na visión de clases tradicional. Esa autodefinición de «movemento de movementos», que goza de especial predicamento en Italia, subliña os aspectos positivos das identidades heteroxéneas e polifacéticas que reflicten a complexidade social, como adoitan destacar os activistas. Nesta dirección, un estudo sobre grupos de interese realizado con activistas do Foro Social de Florencia indicou a aparición de identidades tolerantes, caracterizadas pola súa visión inclusiva e pola relevancia que se lle concede a unha fertilización recíproca, que se considera beneficiosa, e cun sentido limitado da identificación (Della Porta 2005; tamén Della Porta, Andretta, Mosca e Reiter 2006) ${ }^{3}$. Os activistas presentan a diversi-

\footnotetext{
${ }^{3}$ Traballamos con seis grupos, todos eles constituídos por nós co obxecto de representaren a «alma» fundamental do movemento -diversas posturas ideolóxicas, mais tamén membros «non organizados» (é dicir, aqueles que non pertencían a unha asociación concreta)- e, así mesmo, diferentes graos de compromiso (pero excluíndo os líderes). Ademais, os grupos eran heteroxéneos no referente ao sexo dos integrantes; en cambio, cada un dos seis (formado por unha media de oito participantes) si era homoxéneo con respecto ás xeracións políticas, formadas, respectivamente, por adolescentes (estudantes de ensino superior, de 17 a 20 anos de idade), a nova xeración (de vinte e tantos anos: entre 21 e 27), a "xeración perdida» dos noventa (socializada nun período que se caracterizou pola baixa intensidade das protestas; de 28 a 35 anos), a xeración do 77 (en Italia, anos particularmente radicais; de 36 a 43 anos de idade), a xeración do 68 (de 44 a 59 anos) e a xeración de posguerra (aínda activa; de 60 anos en diante). Malia que no (relativamente) limitado movemento ambiental non resultou posible incluír só persoas que non se coñecían, si tentamos mesturar, tanto como fose posible, membros de organizacións radicadas en diversos puntos e que, polo tanto, mantivesen escasa relación entre eles. Cada grupo reuniuse unha vez e todas as sesións (dunhas dúas horas de duración) se gravaron en casete. As citas tomadas dos grupos de interese refírense ao informe interno I figli dei fori, editado por Elena del Giorgio; a cifra identifica o número do grupo de interese e a letra o participante.
} 
dade como valor positivo; así, un deles falaba «dunha gran novidade e unha enorme baza, porque conxuga homes e mulleres que van desde os vinte aos sesenta anos e que debaten entre eles, en contraposición a esa lóxica dos vellos partidos políticos de esquerdas de poñer á parte as mulleres, a xente nova, etc.» (4E, p. 101). Outro activista engadiu que «o que ten de marabilloso este movemento é a súa variedade e a súa capacidade de congregar os individuos máis diversos arredor de obxectivos que son comúns a todos eles» (1D, p. 10). Un aspecto que se considera que, «en certo modo, marca unha época» é a perspectiva inclusiva deste movemento: o feito de que "haxa un sentimento de pertenza, xaora [...], mais en realidade non son exclusivos, e velaí a novidade [...]». Nas accións conxuntas, os activistas perciben «unha nova vontade de crear fluidez entre as ideas, de as confrontar, sen pretender inclinarse nun sentido ou noutro» (3C, p. 66). Así mesmo, a propia esencia do movemento, o seu «constante devir», enténdese como unha busca de valores, na cal toma parte o activista achegando a súa rica «subxectividade» individual.

Estas diversas correntes de protesta poden interpretarse como unha reacción á redución do Estado do benestar e ao aumento das desigualdades, reacción que lle dá unha nova vitalidade a unha dimensión social do conflito - a "fenda de clases» (Rokkan 1982) - que semellaba, se non calmada, si domesticada. A atención que se lle presta á natureza estrutural dos conflitos sociais descarta a hipótese dunha institucionalización definitiva. Se na década de 1990 o mercado se consideraba a solución aos déficits públicos e ao desemprego, desde o ano 2000 as consecuencias negativas da globalización económica viron a luz pública. Nos seus varios significados e de acordo cos diversos modos de entendela, percíbese que a globalización económica neoliberal -ou o que John Keane (2003) denominou «turbocapitalismo»- é a diana principal á que apuntar. Os conflitos emerxentes reflíctense nas nosas concepcións da cidadanía e centran a súa atención no que a convocatoria do $8^{\circ}$ Congreso Anual da European Sociological Association (Asociación Sociolóxica Europea) definiu como «a sorte corrida polos dereitos civís, políticos e sociais que constitúen o alento vital das sociedades europeas». En Europa, a fin do «equilibrio de mediados de século» entre o capitalismo e o Estado do benestar (Crouch 2004) puxo, deste xeito, os dereitos sociais no centro dos conflitos, aínda que non sen lles prestar atención a outras temáticas (como a sustentabilidade ambiental ou as cuestións de 
xénero) que xurdiran da man dos «novos movementos sociais». Neste sentido, as mobilizacións antes mencionadas puxan por reabrir o debate académico arredor da natureza estrutural dos conflitos, nunha sociedade que xa non se pode definir simplemente como posmaterialista. Os conflitos recentes tamén deixan claro que, como observaron xa hai moito os estudosos da sociedade civil, a construción dunha esfera cidadá que sexa independente do Estado e da economía fai precisa a existencia de dereitos inclusivos para os cidadáns.

\section{OS RETOS DA POLÍTICA: A ANTIPOLÍTICA OU A PROCURA DUNHA NOVA (VELLA) CONCEPCIÓN DA POLÍTICA?}

Ao recuperaren a cuestión dos dereitos sociais, estes conflitos subliñan tamén o importante papel que ha de desempeñar a política fronte ao mercado. Considérase que a política ten moito que dicir á hora de constituír as normas e as institucións da sociedade civil, así como de garantir que se dean as condicións de igualdade e liberdade nas que pode prosperar esa sociedade civil. Se para Habermas o Estado do benestar comporta un risco de intervención do Estado administrativo no mundo-vida, tamén representa, con todo, unha defensa dese mundo-vida contra a penetración da economía capitalista. De modo similar, Jean Cohen e Andrew Arato (1992) reclamaron unha continuación reflexiva das políticas do benestar, necesaria para contrarrestar tanto o risco de colonización polo poder do Estado como a reeconomización da sociedade. Nos estudos dos movementos sociais, ao tempo que se destacan as diferenzas existentes entre eses dous tipos de actores, xúlgase que a apertura das institucións e a presenza de alianzas entre actores políticos institucionais son determinantes para a mobilización colectiva e o éxito desta. Noutros tempos, os antigos movementos e os novos tendían a aliñarse con familias de partidos ou a formar outras.

Desde a década de 1980 vénse notando -e, a miúdo, aprobando- unha división de facto das tarefas entre os partidos e os movementos. Así, mentres que os movementos sociais, as organizacións da sociedade civil e as ONG se «repregaron» cara á esfera social (ou pasaron a constituíla), os partidos políticos-sobre todo os de esquerdas- defenderon as súas demandas (algunhas delas) nas institucións políticas. Ao mesmo tempo apreciouse unha mudanza no repertorio de 
accións colectivas: as obras dedicadas aos movementos sociais destacaron que estes estaban a afastarse dos actos de protesta. As organizacións centradas neses movementos estruturáranse mellor a escala nacional ou mesmo transnacional, fixéranse cunha cantidade substancial de recursos materiais e con certo recoñecemento público, contaban con persoal contratado grazas ao impulso do seu enorme número de membros, e tendían a substituír a protesta por actos de presión ou accións polémicas. Tornáranse en grupos de interese, malia que de interese público; integráranse no sector terciario, adquirindo profesionalidade e, con frecuencia, administrando recursos públicos; ou ben comercializaran as súas actividades e abriran (por veces con éxito) nichos de mercado. Paralelamente, as obras que tratan a sociedade civil destacaron cuestións semellantes ao se centraren nas organizacións máis ricas e mellor estruturadas, influentes mercé aos seus contactos institucionais e á lexitimidade de que gozan entre a opinión pública. Tense dito que a sociedade civil mundial xurdiu do proceso de domesticación dos movementos sociais dos períodos anteriores a 1989, así como do declive das antigas asociacións cívicas (como os sindicatos) e da transformación dos primeiros en ONG (Kaldor 2003).

Para empezar cos repertorios de accións, a meirande parte dos grupos entrevistados para o proxecto DEMOS non se limitan a unha única estratexia, senón que combinan varias (só arredor do 8\% deles declararon centrarse nunha soa, mentres que máis de tres cuartos empregaban polo menos tres), tamén en función da situación política á que se enfrontan ${ }^{4}$. Como amosa a táboa 2 , case o $90 \%$ dos grupos valoran a realización de actividades relacionadas co coñecemento, como a difusión de información, a organización de conferencias, seminarios e obradoiros, a publicación de informes de investigación, etc.; aproximadamente tres cuartos manifestan que realizan actividades de protesta e tamén participan na construción de alternativas concretas; arredor da metade recorren a unha estratexia de presión directa sobre os gobernantes. Xa que logo, en con-

${ }^{4} \mathrm{O}$ cuestionario, semiestruturado e subministrado por teléfono a informantes clave que abranguían 210 organizacións dos movementos sociais, referíase ás características da organización (denominación, ano de fundación, toma interna de decisións, tipos de actividade, tipo de campañas, tipo de organización, tipo de membros, tipo de orzamento e fontes deste) e ás relacións mantidas co ámbito da organización (relación con outros grupos, redes e campañas, interacción con institucións de diversa escala territorial). A campaña de entrevistas realizouse entre xaneiro e agosto de 2006. 
traposición á crenza de que a presión e as protestas son estratexias opostas utilizadas por actores diferentes, nós achamos probas do emprego de ambas por parte dunha porcentaxe significativa dos nosos grupos.

Resulta de especial interese que se insista na elaboración de alternativas concretas. Ao longo das entrevistas, as alternativas concíbense como elementos específicos e postos en práctica: para "construír outros mundos posibles» fai falta «crear contradicións obvias mediante prácticas alternativas» (Rete Lilliput). Porén, «alternativa» tamén se entende como algo rotundamente diferente, posto que o movemento pretende "des-velar / facer visible / denunciar as diferentes formas que emprega o sistema capitalista para lexitimarse, e activar propostas ou alternativas a este sistema» (Baladre); comporta "unha mudanza radical na sociedade e nos estilos de vida» (Tavola della Pace, Italia) e «ofrece unha alternativa ao modelo capitalista» (Les Communistes, Suíza).

Os conflitos emerxentes non só dan fe dunha volta da política ás rúas, senón que tamén poñen en dúbida a idea dunha retirada política; o que se propón, no entanto, é unha visión alternativa dela. Malia que as interaccións que se producen entre a política institucional e a política de base -entre a política habitual e a politica controvertida- seguen a ter importancia, a imaxe dunha especie de repartimento de tarefas entre os partidos (especialmente os de esquerdas) e os movementos estase a tornar en cada vez máis problemática e, sobre todo, é cada vez máis cuestionada polos actores da sociedade civil que teñen unha visión diferente da política (non unha antipolítica, senón unha outra política) e que afirman a súa natureza e a súa función neste eido. A concepción da política que se deriva dos conflitos mencionados é crítica coa política institucional que xurdiu na nosa sociedade, a cal non deixa de profesionalizarse. Aínda que estes conflitos insisten na necesidade de que a economía se goberne desde o ámbito político, reflicten unha crecente tensión entre unha perspectiva representativa da política e outra baseada na participación, separación que tivo a súa expresión simbólica no lema inaugural do desfile internacional realizado en Xénova: «Vosoutros, o G-8; nosoutros, 6000 millóns». De acordo coa primeira perspectiva, nunha democracia representativa moderna a política convértese nunha actividade para profesionais (os líderes do G-8 e demais políticos de profesión) que adoptan decisións lexitimados pola súa investidura electoral. A segunda perspectiva non só articula unha reclamación política, senón que ademais 
TÁBOA 2. ESTRATEXIAS PRINCIPAIS DOS GRUPOS POR PAíS (\%)

Estratexias

País (porcentaxe de respostas afirmativas)

Total

principais

do grupo

$\begin{array}{lllllll}F & \text { A } & \text { I } & \text { ES } & \text { SU } & \text { RU } & \text { TN }\end{array}$

Protesta

$\begin{array}{lllllll}78,6 & 73,1 & 81,1 & 97,1 & 75,0 & 75,9 & 59,3\end{array}$

78,1

Concepción de

alternativas

concretas

Presión

$\begin{array}{lllllll}85,7 & 61,5 & 64,9 & 62,9 & 89,3 & 79,3 & 88,9\end{array}$

75,2

Educación

política /

concienciación

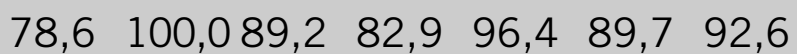

89,5

Total

$\begin{array}{lllllll}13,3 & 12,4 & 17,6 & 16,7 & 13,3 & 13,8 & 12,9\end{array}$

100,0

(N)

(26)

(37)

(35) (28) (29)

(210)

N. B.: a porcentaxe global dunha columna pode ser superior ao $100 \%$ debido á posibilidade de que se ofrecesen respostas múltiples.

Fonte: Della Porta e Mosca (2006)

presenta a proposta dunha "política diferente», é dicir, dunha política da participación levada á práctica en áreas abertas aos cidadáns, entendidos como suxeitos e actores da política.

Entre os activistas, a reclamación política constitúe, antes de máis, unha reclamación de participación; en efecto, unha das principais críticas que se lles fan aos partidos consiste en que agora xa se tornaron en burocracias fundamentadas na delegación. Nos grupos de interese antes mencionados, os partidos resultan estigmatizados por seren portadores dunha idea errónea: a da política en canto algo feito por profesionais, cuxo interese radica, como moito, en explotar os movementos que se produzan, ao tempo que se nega a natureza política destes. No entanto, esas críticas diríxense, en particular, ás afirmacións dalgúns políticos de partido referidas a un «movemento prepolítico que pide que 
o escoiten e que, a seguir, o transformen nun proxecto e un programa político aqueles que se dedican á política no sentido institucional da palabra» (6E, p. 143). En troques, a "política alternativa» experiméntase como a participación dos cidadáns (mesmo «dos individuos») na elaboración de «reivindicacións»e «respostas»: «a cousa xa non é como antes, cando estaban, por unha banda, o movemento, coa súa espontaneidade e a facer preguntas, e, pola outra, os políticos, a daren respostas ou a o intentaren [...] neste caso as respostas veñen acompañadas das preguntas, e as preguntas veñen acompañadas das respostas» (2A, p. 42-43).

Xunto coa reclamación de participación, que certamente non é unha novidade, as organizacións e os activistas de que nos ocupamos subliñaron tamén a súa concepción deliberativa da política, orientada non só ao reconto de preferencias, senón ademais á construción de novas identidades mediante a congregación de diferentes actores nas esferas públicas e nos espazos de libre uso. Como declaraba un activista, "para min, facer política neste sentido, directamente, facer sociedade, facer a polis, é o aspecto máis estimulante» (5E, p. 123).

Esta visión dunha «nova política» está moi espallada entre os grupos que analizamos no proxecto DEMOS. Da análise da súa documentación básica dedúcese que a participación é unha das dimensións principais do xeito en que os movementos sociais entenden a democracia: un terzo das organizacións menciónana como valor interno. Porén, tamén aparecen outros valores que especifican (e diferencian) as diversas concepcións da democracia da participación. Ao estudar os valores democráticos xerais, é de destacar que en nada menos que a metade da nosa mostraxe se identifican referencias á pluralidade, á diferenza e á homoxeneidade como importantes factores democráticos, cuxo valor está moi próximo ao da referencia que se fai á participación nun sentido máis tradicional. De maneira significativa, os valores representativos menciónaos só o $6 \%$ das nosas organizacións. $\mathrm{Na}$ mesma dirección, os activistas destas (de acordo coa enquisa que lles realizamos a 1055 representantes de organizacións da sociedade civil que participaron no cuarto Foro Social Europeo, realizado en Atenas) promoven unha imaxe normativa da democracia que fai fincapé na participación, por riba da delegación (o 75\% deles), mais tamén na busca de consensos mediante o debate (ou as conversas), fronte a unha concepción da democracia entendida como un mero «reconto de preferencias» (para arredor da metade deles) (Della Porta 2009; véxase tamén Della Porta 2007). 
Esta concepción da "política feita desde abaixo» non implica, porén, unha renuncia ás relacións coa política institucional; pola contra, os resultados do estudo confirman que moitas organizacións a prol dos movementos sociais están abertas ás interaccións con institucións de goberno de múltiples niveis. Tal actitude, que contrasta coa interpretación que se fai destas organizacións en canto meras entidades de protesta nas rúas, ou coa percepción da natureza "antipolítica» da sociedade civil, a miúdo declárase expresamente nos escritos fundamentais das organizacións. Volvendo á análise documental do proxecto DEMOS, malia que arredor da metade dos nosos grupos non mencionaron as relacións coas institucións, cando si o fixeron mostráronse moi abertos a interactuaren con elas. Con respecto ás institucións representativas en xeral, son raras as declaracións de rexeitamento rotundo de toda colaboración $(11,5 \%)$, mentres que é máis frecuente unha actitude de colaboración ou ben de control democrático (aproximadamente un terzo cada unha) (Della Porta e Mosca 2006). Os resultados das entrevistas realizadas para o mesmo proxecto son moi compatibles cos obtidos no referente á ideoloxía das organizacións. En resposta á pregunta de «como se relaciona o teu grupo con institucións públicas de diversas escalas territoriais», na nosa mostra de 210 organizacións segue a ser moi infrecuente o rexeitamento de toda colaboración: dun 4,4\% no referido ás institucións locais, cifra moi baixa, a un $11,8 \%$ para a escala nacional e un $13,5 \%$ para a internacional. Os grupos que -ben por lles seren indiferentes as relacións coas institucións, ben porque as institucións as rexeitan- declararon unha ausencia de colaboración son máis numerosos, mais aínda reducidos en número: entre un quinto que colaboraban coa escala local e nacional, e un terzo coa supranacional. O resto das organizacións da mostraxe tenden a colaborar sobre todo coas institucións locais (nada menos que o 70\%) e coas nacionais (67\%), mais tamén con organismos gobernamentais internacionais (case a metade da nosa mostra). Neste punto paga a pena advertir que moitos grupos declaran colaborar simultaneamente con diversos niveis territoriais, o que dá fe da súa adaptación a múltiples niveis de goberno. Porén, tamén neste respecto, os nosos entrevistados adoitan definir a súa colaboración como crítica ou selectiva: manteñen unha actitude menos crítica cos gobernos locais e, en troques, aumenta a súa desaprobación das escalas nacionais e supranacionais. 
Estes mesmos resultados poñen en dúbida a concepción dos movementos e dos dereitos cidadáns como entidades limitadas ao interior das fronteiras nacionais. Sen significaren a morte do Estado-nación nin a fin da democracia representativa, as transformacións experimentadas tanto polos límites dos sistemas de goberno como polos principais actores políticos afectan o funcionamento tradicional do Estado democrático. Porén, insistir exclusivamente na importancia das oportunidades que se presentan no ámbito nacional non axuda a entender uns actores que non só abordan os problemas a escala mundial, senón que tamén se organizan cada vez máis en redes transfronteirizas. Así, un número superior á metade dos entrevistados declarou que a súa organización colabora con organismos gobernamentais internacionais, pero ademais tres cuartos deles afirmaron que tomaran parte en actos de protesta transnacionais; a mesma porcentaxe, que se identificaban cun movemento global; e nada menos que o $80 \%$ mencionaban nos seus documentos fundacionais, como unha das principais estratexias da organización, a colaboración ou a conexión con organizacións transnacionais a prol dos movementos sociais. Estes datos dan fe dunha dimensión transnacional (ou mundial) cada vez maior, que as reflexións sobre a sociedade civil comezaron a abordar antes que os estudos dos movementos sociais, tradicionalmente máis arraigados na perspectiva nacional.

TÁBOA 3. RELACIÓN COAS INSTITUCIÓNS SEGUNDO OS ENTREVISTADOS (EN PORCENTAXE; NÚMERO DE ENQUISADOS: 200-203)

\begin{tabular}{llll} 
& $\begin{array}{l}\text { Institucións } \\
\text { locais }\end{array}$ & $\begin{array}{l}\text { Institucións } \\
\text { nacionais }\end{array}$ & $\begin{array}{l}\text { Institucións } \\
\text { internacionais }\end{array}$ \\
\hline $\begin{array}{l}\text { Rexeitamento da } \\
\text { colaboración }\end{array}$ & 4,4 & 11,8 & 13,5 \\
\hline $\begin{array}{l}\text { Indiferenza / ausencia de } \\
\text { contactos / negativa das } \\
\text { autoridades que colaboran }\end{array}$ & 22,8 & 21,2 & 32,5 \\
\hline $\begin{array}{l}\text { Colaboración crítica / } \\
\text { selectiva }\end{array}$ & 29,7 & 34,5 & 24,5 \\
\hline $\begin{array}{l}\text { Colaboración } \\
\text { Fonte: Della Porta e Mosca (2006) }\end{array}$ & 39,1 & 32,5 & 20,5 \\
& & &
\end{tabular}


En conclusión, os conflitos emerxentes denotan un retorno á política na rúa, mais tamén subliñan unha concepción da política alternativa á expresada na democracia representativa, que vai topando cun número de dificultades cada vez maior ante fenómenos tan expandidos como o declive das lealdades aos partidos, a redución do Estado e a aparición de diversas formas de globalización. $\mathrm{Na}$ análise da sociedade civil, a "volta á política» vivida na década do 2000 puxa cara a unha redefinición dese espazo (que nunca ficou claro de todo; Kumar 1993) que existe entre o público e o privado, o social e o político. Mentres que a abundante reflexión sobre a sociedade civil dera por feita a diminución do Estado, os conflitos emerxentes apuntan a un aumento das reivindicacións a prol dun retorno da política, tanto nas nosas sociedades como no noso teorizar sobre elas. As voces que reclaman independencia do Estado non se debilitaron, mais un sector cada vez maior das organizacións da sociedade civil percibe que esa demanda vai parella á avaliación da natureza, plenamente política, das súas propias actividades. Pola súa banda, os estudos dos movementos sociais teñen que tratar os desafíos aos que se enfronta a noción dun repartimento de tarefas entre a política controvertida e a non controvertida a raíz da aparición de organizacións internacionais gobernamentais e do declive (das funcións identificadoras) dos partidos políticos nacionais.

\section{A SOCIEDADE CIVIL COMO PRODUTO DA PROTESTA? ALGUNHAS CONCLUSIÓNS}

Os estudos sobre a sociedade civil, así como os dedicados aos movementos sociais, poden axudarnos a entender o papel que desempeñan os conflitos como o aquí analizado na creación dun espazo cidadán, ao cal se referiu Giovanna Procacci no seu discurso presidencial pronunciado no $8^{\circ}$ congreso da ESA. Un factor que se adoita subliñar nas obras que tratan os movementos sociais e a sociedade civil é a importancia que reviste manter unha rica vida asociativa para que se desenvolvan os movementos sociais e unha sociedade civil autónoma.

O substantivo papel que desempeñan as redes de organizacións á hora de dispoñer de recursos vese confirmado polas recentes mobilizacións. A descrición que elaborei apunta ao relevante que é volver mobilizar redes (ou movementos) 
xa existentes que contan cunha tradición histórica, a miúdo extensa, nas campañas de protesta da década dos 90 e de principios da de 2000. As mobilizacións que se veñen producindo desde o ano 2000 son o resultado dun proceso duradeiro de creación de vínculos e de intensificación da solidariedade entre diversas correntes de anteriores movementos progresistas no transcurso de campañas transnacionais. Desde esta perspectiva, a nosa historia confirma a importancia de dispoñer de recursos para a mobilización, como levan destacando desde os anos 70 os estudos dos movementos sociais e como confirmaron despois as reflexións sobre a sociedade civil.

Non obstante, os recentes conflitos tamén apuntan aos efectos que teñen as protestas en si na construción dos recursos de confianza e solidariedade que son necesarios para crear espazos de cidadanía. A reivindicación dos dereitos sociais e a esixencia da responsabilidade política necesaria para poñelos en práctica, mais tamén a demanda de que se conciban inmediatamente alternativas e organizacións a prol dos movementos sociais e da sociedade civil, non só esgotan o capital social, senón que tamén o producen. Mentres que os estudos dos movementos sociais se centran nas protestas como variable independente, analizando como se ven favorecidas polo capital social, e mentres que as obras dedicadas á sociedade civil destacan a función dos grupos «apolíticos» e «cooperativos» da sociedade civil, os novos conflitos apuntan ao papel que desempeñan as protestas en canto entidade emerxente que conduce a unha sociedade civil.

As investigacións sobre redes en movemento xa insistiran en que a superposición de membros facilita a integración dos diferentes eidos que abranguen os movementos: fai máis doado «o contacto persoal e a creación de redes informais que, pola súa vez, fomentan a participación individual e a mobilización de recursos» (Della Porta e Diani 2006: 128). De feito, a) «facilitan a circulación de información e, polo tanto, aumentan a velocidade do proceso de toma de decisións»; b) «facilitan o desenvolvemento de representacións compartidas do conflito»; c) contribúen ao "crecemento dunha confianza mutua» (ibíd., 128-129; véxase tamén Diani 1995, e Carrol e Ratner 1996). Dun xeito semellante, na percepción subxectiva dos activistas defensores dos movementos sociais, as recentes campañas de protesta contribuíron á mobilización ao alimentaren o desenvolvemento de normas inclusivas, dunha identidade transnacional e de marcos transversais, e ao aumentaren a confianza recíproca. 
A creación de redes «de acción» percíbese, primeiramente, como un elemento de grande importancia para aumentar a influencia de cada unha das organizacións e dos individuos. A coordinación comeza no terreo pragmático, o de facilitar a mobilización, e a seguir contribúe á elaboración de normas inclusivas. A lóxica da rede en canto instrumento de coordinación da actividade permite a participación de diversos actores políticos; de feito, a miúdo a rede mantense principalmente grazas á importancia que se lle concede á mobilización en prol duns obxectivos concretos. Mais, á parte deste fin instrumental, as campañas de protesta constitúen espazos onde pode xurdir un entendemento mutuo (Della Porta e Mosca 2007; Della Porta 2008). Cando as accións emprendidas en redes transnacionais levan a recoñecer as semellanzas existentes entre países, faise posible a construción dunha identidade transnacional. Así, durante un proceso de cambio de escala (Tarrow 2005; Tarrow e McAdam 2005), no decorrer dunha campaña transnacional os activistas empezaron a identificarse como parte dunha entidade europea ou mesmo mundial. Ademais, os activistas tamén xulgan que este entendemento mutuo é un antídoto contra as reivindicacións centradas nunha soa temática: abofé, a superposición de membros e a participación en coalicións de organizacións considéranse condicións previas para poder difundir ideas innovadoras (sobre os movementos feministas e pacifistas, véxase Meyer e Whittier 1994).

Participar en campañas de protesta tamén contribúe ao coñecemento mutuo e, polo tanto, á confianza «na acción». Desde esta perspectiva, os activistas entrevistados no transcurso dun estudo sobre os foros sociais de Italia ${ }^{5}$ subliñan que aumentou o diálogo entre líderes (ou voceiros) de diversas organizacións como consecuencia de chegar a un mellor entendemento mutuo durante a realización de campañas conxuntas: «logo de varios anos de emprender accións todos xuntos, un atópase con outros no mesmo movemento, conversa, comeza a entendelos, atopa códigos de comunicación, métodos para resolver os problemas [...]

${ }^{5}$ Leváronse a cabo entrevistas pormenorizadas a representantes de 20 organizacións que se amosaban activas nas cuestións da problemática laboral e do desenvolvemento e a solidariedade internacionais. As entrevistas foron realizadas por Lorenzo Mosca entre maio e novembro de 2004, nas que empregou un cuestionario estruturado e centrado na historia das asociacións, a súa estrutura organizativa e a súa metodoloxía de toma de decisións, as modalidades de acción e os eidos en que se enmarcaban con referencia aos procesos de globalización e ao movemento antiliberal de Italia. Para obter máis información, véxase Della Porta e Mosca (2006). 
nas diferentes mobilizacións un coñece diversos actores organizados ou non organizados cos que antes non tiña nada que ver [...] aí un empeza a participar nun diálogo e a descubrir que se poden facer cousas xuntos» (entrev. 2, p. 14-15). Así mesmo, no que respecta aos membros de base, as campañas comúns eles percíbenas como un factor que permite o crecemento dunha familiaridade mutua que contribúe á construción de obxectivos comúns, xa que o coñecemento fai posible que se superen os prexuízos. Como apunta un entrevistado: «tamén chegamos a coñecernos entre nós e a moderar determinadas actitudes, e existe confianza e respecto ante todo tipo de representación incluído no comité» (entrev. 11, p. 6).

Estas historias de campañas de protesta constitúen un acicate para a procura dun equilibrio entre a venerable tradición sociolóxica, que recoñece o papel fundamental que desempeñan os conflitos á hora de fomentar a solidariedade, e sen dúbida conceptos como a reciprocidade, a urbanidade, o diálogo, o respecto, que exerceron unha influencia capital nas reflexións sobre a sociedade civil. Lonxe de tornaren inútiles as vellas categorías sociolóxicas, estes retos son para nós un estímulo que nos empuxa a considerar os movementos sociais e outros que están a nacer en canto actores capaces de producir recursos na acción. De feito, podemos chegar a entender mellor as nosas sociedades grazas á fertilización recíproca que chegue a existir entre diversos ámbitos de investigación; en particular, teño argumentado que os estudos dos movementos sociais fixeron a súa achega ao centrárense nos conflitos e ao analizaren a función política dos actores sociais, mentres que a reflexión sobre a sociedade civil dirixiu a súa atención cara ao equilibrio existente entre a emancipación do Estado e a do mercado, así como cara ao papel que desempeñan as normas de confianza e de reciprocidade. A fertilización recíproca pode ser máis frutífera posto que, en ambos os eidos, a recente vaga de protestas levou a que os movementos sociais e as organizacións da sociedade civil recibisen unha maior atención por parte de estudosos (a miúdo novos) das disciplinas das ciencias sociais, ademais da socioloxía e das ciencias políticas, en eidos tan variados como a antropoloxía e as relacións internacionais, e da teoría social á historia. 


\section{BibliografíA}

AleXander, Jeffrey C.: "Introduction. Civil Society I, II, III: Constructing an empirical concept from normative controversies and historical transformations», en Jeffrey C. ALEXANDER: Real Civil Society. Dilemma of institutionalization. Londres, Sage, 1998, p. 1-20.

Carroll, William K. e R. S. Ratner: «Master Framing and Cross-Movement Networking in Contemporary Social Movements», Sociological Quarterly, 37 (1996), p. 601-625.

Chandoke, Neera: The Concepts of the Civil Society. New Delhi, Oxford University Press, 2003.

Cohen, J.: Deliberation and Democratic Legitimacy, en A. Hamlin e P. PeTTIT (eds.): The Good Polity. Oxford, Blackwell, 1989, p. 17-34.

Cohen, Jean L. e Andrew Arato: Civil society and political theory. Cambridge, MIT Press, 1992.

Crouch, Colin: Post Democracy. Londres, Polity, 2004.

Della PORTA, Donatella (ed.): The Global Justice Movement. Cross National and Transnational Perspective. Boulder, CO, Paradigm, 2007.

Della Porta, Donatella (ed.): Democracy in Social Movements. Palgrave Macmillan, 2009.

Della Porta, Donatella e Herbert ReITER: Organizational Ideology and Vision of Democracy in the Global Justice Movement, WP3 Report, Democracy in Movement and the Mobilization of Society - DEMOS, European Commission, 2006.

Della PORTA, Donatella e Lorenzo MosCa: Searching the Net, WP2 Report, Democracy in Movement and the Mobilization of Society - DEMOS, European Commission, 2005.

Della PORTA, Donatella e Lorenzo MosCA: "In movimento: "contamination" in action and the Italian Global Justice Movement», Global Networks: A journal of transnational affairs, 7, n.o 1 (2007), p. 1-28.

Della PORTA, Donatella: Eventful Protest, Global Conflicts, prepared for presentation at the plenary session of the Conference of the Nordic Sociological Association, Aarhus, agosto de 2008.

Della Porta, Donatella e Mario Diani: Social Movements. An Introduction. Oxford, Blackwell, 2006.

Della PorTA, Donatella, Massimiliano Andretta, Lorenzo Mosca e Herbert ReITER: Globalization from Below. Minneapolis, The University of Minnesota Press, 2006.

DiAnI, Mario: Green Networks. A Structural Analysis of the Italian Environmental Movement. Edimburgo, Edinburgh University Press, 1995.

DryzeK, John S.: Deliberative Democracy and Beyond. Nova York, Oxford University Press, 2000.

Kaldor, Mary: Global Civil Society. An Answer to War. Cambridge, Polity Press, 2003.

KEAne, John: Global Civil Society? Cambridge, Cambridge University Press, 2003.

KITSCHELT, Herbert: Landscape of Political Interest Intermediation: Social Movements, Interest Groups and Parties in the Early Twenty-First Century, en Pedro IBARRA (ed.): Social Movements and Democracy. Nova York, Palgrave Macmillan, 2003, p. 105-136.

KumAR, Krishan: "Civil Society: An Inquiry into the Usefulness of an Historical Term», The British Journal of Sociology, vol. 44, n. 3 (1993), p. 375-395.

LIPSKY, Michael: Protest and City Politics. Chicago, Rand McNally \& Co, 1965.

Mansbridge, Jane: «Using Power/Fighting Power: The Polity», en Seyla BenhabiB (ed.): Democracy and Difference: Contesting the Boundaries of the Political. Princeton, Princeton University Press, 1996, p. 46$-66$.

MATHERS, Andy, Struggling for Another Europe. Aldershot, Ashgate, 2007. 
Meyer, David S e Nancy WhitTier: «Social Movements Spillover», Social Problems, 41 (1994), p. 277$-298$.

MiTZAL, Barbara: Civil Society: A signifier of plurality and sense of wholeness, en Judith R. BLAU (ed.): The Blackwell Companion of Sociology. Oxford, Blackwell, 2001, p. 73-85.

OBersCHAll, Anthony: Social Conflict and Social Movements. Englewood Cliffs, N. J., Prentice Hall, 1973.

Offe, Claus: Microaspects of Democratic Theory: What Makes for the Deliberative Competence of Citizens?, en A. Hadenius (ed.): Democracy's Victory and Crisis. Nova York, Cambridge University Press, 1997, p. 81-104.

RoKKAn, Stein: Cittadini, Elezioni, Partiti. Boloña, Il Mulino, 1982. (Edición orixinal: Citizens, Elections, and Parties. Oslo, Oslo University Press, 1970).

RUCHT, Dieter: «Un movimento di movimenti? Unità e diversità fra le organizzazioni per una giustizia globale», Rassegna italiana di sociologia, 46 (2005), p. 275-306.

SaVaGe, Mike: Political Sociology, en Judith R. Blau (ed.), The Blackwell Companion of Sociology. Oxford, Blackwell, 2001.

TARrow, Sidney e Doug McAdaM: «Scale Shift in Transnational Contention», en D. della PORTA e S. TARROW (eds.): Transnational Protest and Global Activism. Lanham, Rowman and Littlefield, 2005, p. 121-149.

TARrow, Sidney: The New Transnational Contention. Nova York / Cambridge, Cambridge University Press, 2005.

Tilly, Charles: From Mobilization to Revolution. Reading, MA, Addison-Wesley, 1978.

TOURAINE, Alain: The Self-Production of Society. Chicago, University of Chicago Press, 1977. 